\title{
Varmus deft with Senate on NIH strategy
}

Washington. Harold Varmus, directordesignate of the US National Institutes of Health (NIH), appeared before the Senate last week for confirmation hearings that, while calm on the surface, nonetheless revealed an undertow of potential conflict.

Members of the Senate Committee on Labor and Human Resources, chaired by Edward Kennedy (Democrat, Massachusetts), took turns praising Varmus as a literary scholar (he has a deep interest in seventeenth-century literature) and as a star scientist who would be NIH's first director with a Nobel prize. Varmus and Michael Bishop shared the 1989 prize for physiology or medicine for their discovery that viral cancers derive from cellular genes or oncogenes.

But a barrage of questions from the committee made it clear that Varmus will have no easier a time than his predecessors in dealing with Congress's long-standing habit

of trying to determine the details of the NIH's research portfolio by focusing on diseases of special interest to individual members and their constituents

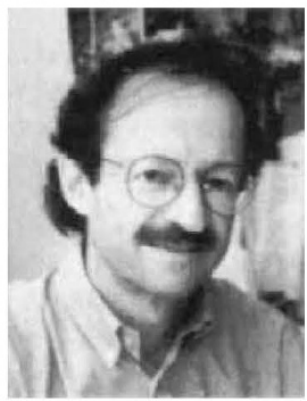

Varmus: will need 'a lot of steel'.
Only minutes into the hearing, Christopher Dodd (Democrat, Connecticut), admitting that he might be unfairly raising a subject beyond Varmus's knowledge, repeated the story of a little girl with an unusual urea cycle disease that is being treated at NIH. Only 124 people have the disease, and the US Food and Drug Administration has yet to approve the experimental drug

\section{Popovic wins appeal against ORI charges}

Washington. Mikulas Popovic, the former US National Institutes of Health (NIH) researcher who succeeded in 1983 and 1984 in growing the human immunodeficiency virus (HIV) in sufficient quantities to develop a blood test, has been cleared of all charges of scientific misconduct in writing up the paper in which he reported his data.

After years of investigation into questions about the integrity of certain words and figures in the 1984 paper, coauthored with his laboratory chief Robert C. Gallo and published in Science. NIH found Popovic, who worked at the National Cancer Institute at the time, guilty of misleading readers on four counts.

In one, for instance, the NIH's Office of Scientific Integrity (OSI), found him guilty of misconduct for using the initials ND (for 'not done') in a table in which the 'ND' experiments clearly had been done (even though it agreed that this in no way altered the scientific validity of the paper).

The OSI, and then its supervisory (and now successor) agency, the Office of Research Integrity (ORI), rejected Popovic's argument that he meant ND to mean 'not determined', as well as claims that ND is used in the literature with both meanings. Popovic appealed his conviction for misconduct on this and other similar counts to the Departmental Appeals Board within the Department of Health and Human Services, the highest court of appeals within the government's internal disciplinary system.

The appeals board, whose members are all trained in law, held a 12-day hearing of the charges. On 3 November, it issued its judgement, saying: "One might anticipate that from all this evidence [presented by OSI and ORI], after all the sound and fury, there would be at least a residue of palpable wrongdoing. That is not the case."

The board said that the OSI and the ORI, which had been both accusers and judges of Popovic, were bound by the normal legal standard that conviction requires proof of guilt by a "preponderance of the evidence", rather than by a pyramid of assumptions built on a foundation of inferences. "Specifically, ORI did not prove that the Science paper contains untrue statements or data, much less that it contains intentional falsifications," the board said in its 79-page opinion.

The board rebuts the ORI's case pointby-point and emphasizes that a finding of scientific misconduct, which stigmatizes researchers and can deprive them of their livelihood, must be based on legally supportable evidence. Popovic was unemployed for about three of the five years that his case has been making its way through the system.

ORI's director, Lyle Bivens, says that if his agency has to meet the appeals board's standards of proof and intent to deceive, it will have a hard time proving misconduct. The board's response is that that is as it should be, because the stakes for the accused are so high.

Unless ORI tries to interest the US Justice Department - where standards of guilt would be equally high - in filing criminal charges against Popovic, the board's decision represents the last hurdle for Popovic, who has run up legal fees of close to a quarter of a million dollars. He is now working in a laboratory at the Karolinska Institute in Stockholm, Sweden. But he says that, even after everything he has been through, he would still like to return to the NIH. used for its therapy. Varmus, well-briefed and thinking quickly, reassured Dodd that NIH would not abandon the urea cycle patients, however few they may be.

Barbara Mikulski(Democrat, Maryland), in whose state NIH is situated, instructed Varmus to pay attention to one of her favourite causes, women's health, and said she would visit him soon to talk about it. Varmus may well ask Ruth Kirschstein, former director of the National Institute for General Medical Science, NIH's most basic-research institute, and interim head of women's studies, to sit in. Varmus has already announced that Kirschstein will be the NIH's new deputy director.

Paul Wellstone (Democrat, Minnesota) raised the issue of Parkinson's disease. Both his mother and father have the disease, he told Varmus, adding that NIH was not doing enough for these patients.

Varmus replied by explaining that Parkinson's is a disease of the basal cell ganglia. Drawing on what is likely to be the underlying theme of his tenure at NIH, Varmus tried to convince Wellstone that much basic research - such as that in the neurosciences - is directed at diseases such as Parkinson's, even though it might not be labelled as such on the budget tables.

Wellstone, for his part, seemed politely unconvinced and said he would like to "visit with" Varmus about this again. But Varmus maintained his defence of basic research. "As an investigator who has seen the pursuit of an obscure chicken virus create a new vision of human cancer, I will defend openended basic science against the calls for restricted applications of what is already known," he said. Dan Coats (Republican, Indiana) told Varmus that, as leader of NIH, he will "need a lot of steel". Coats did not mean it as a joke.

Perhaps next time Varmus should borrow a trick from Ross Perot, and come armed with a set of eye-catching charts to show the links between basic science and the diseases that dominate the congressional and public mind.

Barbara J. Culliton

\section{Research funds grow}

Capetown. Spending on research and development in South Africa went past the one per cent level of gross national product for the first time in 1991/2, according to the latest biennial survey, compiled for the first time by the Science Policy Unit of the Foundation for Research Development.

Expenditure, at 1.04 per cent of GDP, represents a significant increase since 1989/ 90 , when it stood at 0.86 per cent. But William Blankley, a researcher at the unit, feels that the increase can be explained in part by the inclusion of more companies in the survey.

Michael Cherry 